\title{
KEBIASAAN (`ADAH) DALAM PERPEKTIF HUKUM ISLAM
}

\author{
Ramadhan Syahmedi Siregar \\ Lecturer of Syariah Faculty in UIN North Sumatera Medan \\ Jalan Williem Iskandar Pasar V, Medan Estate, Medan, Sumatera Utara 20371 \\ Email: ramedi1975@gmail.com
}

\begin{abstract}
Islamic law looked a habit ('adah) is a very important part for the development of Islamic law. Since applying toxicity is an urgent sub of worship in Islam. One thing that is not realized, that the habit can form a significant legal and able to answer the question of life and human life as well as a spectacular rituals and in line with local preferences.
\end{abstract}

Keywords: Habits ('adat), Law, Islam, Worship.

\begin{abstract}
Abstrak
Hukum Islam memandang suatu kebiasaan ('adah) merupakan bagian yang amat penting bagi perkembangan hukum Islam. Karena mengaplikasikan kebisaan adalah satu sub dari ibadah yang urgen dalam Islam. Suatu hal yang tidak disadari, bahwa kebiasaan dapat membentuk sebuah hukum yang signifikan dan mampu menjawab persoalan hidup dan kehidupan manusia sekaligus menjadi ritual ibadah yang spektakuler dan searah dengan keinginan masyarakat setempat.
\end{abstract}

Kata Kunci: Kebiasaan (‘adah), Hukum, Islam, Ibadah.

\section{PENDAHULUAN}

Hukum Islam merupakan bagian dari sistem dinul Islam sehingga tidak dapat dipisahkan dari aspek ajaran Islam yang lain, seperti ajaran tentang keyakinan (al-ahkam al'itiqadiyyyah) dan ajaran tentang etika (ahkam al-khuluqiyyah). Pelaksanaan hukum Islam atau ajaran Islam merupakan salah satu wujud nyata dari refleksi keimanan seseorang kepada Allah, yang dalam proses pelaksanaannya tetap berada dalam bingkai akhlakul karimah. ${ }^{1}$ Ajaran Islam atau hukum Islam merupakan hasil dari kegiatan deduktif (istinbathiy) para ilmuan Alqur'an dan hadis. Akan tetapi dalam kenyataannya tidaklah selalu demikian. Para ilmuan itu juga mempertimbangkan kenyataan-kenyataan dan nilai-nilai yang hidup di tengah-tengah masyarakat (al-`urf). Kenyataan dan nilai-nilai itu dihargai sebagai sumber dan dalil setelah mendapat pembenaran dari Alqur’an. ${ }^{2}$

Allah menciptakan manusia untuk beribadah kepada-Nya. Dalam rangka melakukan ibadah tersebut, manusia telah diberikan pertunjuk oleh-Nya. Petunjuk Allah tersebut

${ }^{1}$ Dedi Ismatullah, Sejarah Sosial Hukum Islam, (Bandung: Pustaka Setia, 2011), hlm. 49.

2 M. Yasir Nasution, Hukum Islam dan Signifikansinya dalam Kehidupan Masyarakat Modern, Pidato Pengukuhan Guru Besar IAIN-SU tanggal 7 Januari 1995, hlm. 11. 
dinamakan al-Din atau al-Millah (Islam). Untuk menjalankan perintah itu semua, Allah telah memberikan syari`at kepada manusia di bawah bimbingan dan petunjuk rasul-Nya. ${ }^{3}$ Allah menurunkan syari at hukum Islam untuk mengatur kehidupan manusia, baik selaku pribadi maupun selaku anggota masyarakat. Hal ini berbeda dengan konsep hukum di luar Islam yang hanya ditujukan untuk mengatur kehidupan manusia selaku anggota masyarakat (odening van het social leven). Dalam pandangan hukum di luar Islam, bahwa hukum itu sebagai hasil proses kehidupan manusia bermasyarakat, sebagaimana yang diungkapkan oleh Cicero, bahwa "Ubi Societas Ibi Ius", (di mana ada masyarakat di sana ada hukum). Dalam tata aturan hukum di luar Islam, aturan yang berkaitan dengan kehidupan pribadi tidak dinamakan hukum, ia dinamakan norma " "moral", "budi pekerti", atau "susila". 5

Hukum Islam melarang perbuatan yang pada dasarnya merusak kehidupan manusia, sekalipun perbuatan itu disenangi oleh manusia dan tanpa merugikan orang lain. Seperti meminum minuman keras yang memabukkan (khamr). Dalam pandangan Islam perbuatan itu tetap dilarang, karena dapat merusak akalnya yang seharusnya ia pelihara, meskipun ia membeli minuman itu dengan uangnya sendiri dan diminum di rumahnya tanpa mengganggu orang lain. Demikian juga halnya dengan perbuatan hubungan seksual di luar nikah (zina). Hal tersebut dilarang meskipun mereka yang melakukannya itu dengan suka sama suka, tanpa paksaan dan tidak merugikan orang lain. Hal yang sama juga dengan bunuh diri, membakar harta miliknya, memakan bangkai, membuang jam tangan. Sekalipun hal itu tidak merugikan orang lain, namun tetap dilarang dalam Islam karena orang yang melakukan perbuatan itu tetap akan dimintai pertanggungjawaban di akhirat kelak, sekalipun di dunia tidak terkena hukuman. ${ }^{6}$

Berkaitan dengan penjelasan di atas, pemakalah akan membahas lebih lanjut tentang adat ibadah, yang akan akan menguraikan apakah suatu perbuatan yang dilakukan itu

\footnotetext{
3 Suparman Usman, Hukum Islam: Asas-asas dan Pengantar Hukum Islam dalam Tata Hukum Indonesia, (Jakarta: Gaya Media Pratama, 2001), hlm. 16.

${ }^{4}$ Norma yang mengatur segala macam hubungan antar individu dalam masyarakat ada 4 macam, pertama, norma agama; yakni norma yang berpangkal pada kepercayaan adanya Tuhan Yang Maha Kuasa, dan menganggap norma agama ditentukan oleh Allah di alam semesta ini. Pelanggaran terhadap norma agama berarti pelanggran terhadap perintah Tuhan yang akan mendapat hukuman di akhirat kelak. Kedua norma kesusilaan, yang berpangkal pada hati nurani manusia sendiri, yang membisikkan agar melakukan perbuatanperbuatan yang baik dan meninggalakan perbuatan yang tercela. Pelanggaran terdapa norma susila berarti melanggar perasaan baiknya sendiri yang berakibat penyesalan. Perbuatan yang tidak mengindahkan norma susila disebut a-susila. Ketiga norma kesopanan, yang timbul atau diadakan dalam suatu masyarakat, yang mengatur sopan santun dan perilaku dalam pergaulan hidup antar sesama masyarakat, norma ini didasarkan pada kebiasaan, kepantasan atau kepatutan dalam masyarakat. Orang yang melakukan pelanggran terhadap norma kesopanan akan dicela oleh sesama anggota masyarakat. Semisal jangan berlaku sombong. Meskipun norma agama, kesusilaan dan kesopanan memegang peranan yang sangat penting dalam pergaulan hidup di masyarakat, namun ketiga norma tersebut belum cukup menjamin keserasian, keharmonisan dan keseimbangan hubungan sesama anggota masyarakat, dan belum menjamin segala kepentingan anggota masyarakat. Karenanya ketiga norma itu perlu ditambah dengan norma yang lain yakni norma keempat yaitu norma hukum.

${ }^{5}$ Ibid., hlm. 65.

${ }^{6}$ Ibid.
} 
merupakan kategori hanya sebatas kebiasaan, urf (adat) atau perbuatan itu langsung merupakan sebuah perbuatan ibadah yang nantinya akan diberikan ganjaran (pahala), pertanggungjawaban, atau ia hanya perbuatan yang tidak punya nilai apapun sama sekali dalam pandanga Allah SWT. dan tidak akan dipertanggungjawabkan.

\section{PENGERTIAN `ADAH (URF) DALAM PERSPEKTIF HUKUM ISLAM}

Adat ('adah) dalam bahasa Arab sinonim dengan kata urf, secara literal kata `adah berarti kebiasaan, adat, atau praktek, sementara arti kata urf adalah sesuatu yang telah diketahui. M. Mustafa Syalabi memberikan pengertian yang berbeda antara 'adah dengan urf. 'Adah secara lughawi adalah "pengulangan atau praktek yang sudah menjadi kebiasaan, yang dapat digunakan baik untuk kebiasaan individual ('adah fardiyah) maupun kelompok ('adah jama 'iyah) ${ }^{7}$ di sisi lain urf didefenisikan sebagai sesuatu yang dikerjakan secara berulang-ulang tanpa adanya hubungan rasional. ${ }^{8}$ Sebahagian yang lain memberikan definisi bahwa adat adalah praktek yang berulang-ulang yang dapat diterima oleh seseorang yang mempunyai akal sehat.

Dengan demikian menurut pengertian di atas urf lebih merujuk kepada suatu kebiasaan dari sekian banyak orang dalam suatu masyarakat, sementara ’adah lebih berhubungan dengan kebiasaan sekelompok kecil orang tertentu saja. Meskipun demikian beberapa fuqaha' yang lain memahami kedua kata tersebut sebagai dua kata yang tidak berlainan ${ }^{9}$ demikian menurut pendapat Subhi Mahmasani.

\section{MACAM-MACAM URF (KEBIASAAN) DALAM HUKUM ISLAM}

Para ulama ushul fiqh membagi urf kepada tiga macam: ${ }^{10}$

1. Dari segi objeknya urf dibagi kepada dua macam: ${ }^{11}$

a. al-Uruf al-lafzhi adalah kebiasaan masyarakat dalam mempergunakan lafal/ungkapan tertentu dalam mengungkapkan sesuatu, sehingga makna ungkapan itulah yang difahami dan terlintas dalam pikiran masyrakat. Misalnya ungkapan "daging" mencakup seluruh daging yang ada. Apabila seseorang mendatangi penjual daging, sedangkan penjual daging itu memiliki bermacam-macam daging, lalu pembeli mengatakan "saya beli daging satu kilogram", pedagang itu langsung mengambilkan

${ }^{7}$ M. Mustafa Syalabi, Ushul al-Figh al-Islami (Beirut: Dar an-Nahdah al- 'Arabiyah, 1986), hlm. 313-315.

${ }^{8}$ Lihat juga Nasrun Haroen, Ushul Figh I, (Jakarta: Logos Wacana Ilmu, 1997), hlm. 138.

${ }_{9}$ Subhi Mahmasani, Filsafat at-Tasyri fi al-Islam (Beirut: Dar al-Kasysyaf lin-Nasyr wa at-Tiba ah wa atTauzi, 1952), hlm. 179-181. Urf menurut etimologi adalah: sesuatu yang dipandang baik, semantara secara terminologi: Sesuatu yang tidak asing lagi bagi satu masyarakat karena telah menjadi kebiasaan dan menyatu dengan kehidupan mereka baik berupa perbuatan atau perkataan. Atau sesuatu yang dikerjakan secara berulangulang tanpa ada hubungan rasional.

10 Ahmad Fahmi Abu Sunnah, al-'Urf wa al-'Adah fi Ra`yu al-Fuqaha', (Mesir: Dar al-Fikr, al-'Arabi, t.t.), hlm. 8 .

${ }^{11}$ Nasrun Haroen, hlm. 139. 
daging sapi, karena kebiasan masyarakat setempat telah menkhususkan penggunaan kata daging pada daging sapi.

b. al-Uruf al-'amali adalah kebiasaan masyarakat yang berkaitan dengan perbuatan biasa atau mu'amalah keperdataan. Adapun yang dimaksud dengan "perbuatan biasa" adalah perbuatan masyarakat dalam masalah kehidupan mereka yang tidak terkait dengan kepentingan orang lain, seperti kebiasaan libur kerja pada hari-hari tertentu dalam satu minggu, kebiasaan masyarakat tertentu memakan makanan khusus atau minuman tertentu dan kebiasaan masyarakat dalam memakai pakaian tertentu dalam acaraacara khusus. Contoh lain kebiasaan masyarakat membeli produk elektronik (kulkas) dengan mengantarnya ke rumah tanpa ada biaya transport tambahan.

2. Dari segi cakupannya 'urf terbagi dua;

a. urf 'am: kebiasaan tertentu yang berlaku secara luas di seluruh masyarakat dan seluruh daerah, misalnya dalam jual beli mobil baru, seluruh alat yang diperlukan untuk memperbaiki mobil seperti kunci, tang, ban serep sudah termasuk dalam harga jual tanpa akad dan biaya tambahan. Atau jual rumah second sudah termasuk kunci, jendela atau kusen, pam, listrik. Juga kebiasaan bagi penumpang pesawat hanya dibolehkan membawa barang bawaannya seberat $20 \mathrm{~kg}$.

b. urf al-khas; kebiasaan masyarakat yang berkaitan dengan di daerah dan masyarakat tertentu. Misal bila ada cacat dalam jual beli dapat dikembalikan (khiyar) ‘aib, majlis dan syarat. Contoh lain menyewa jasa pengacara dengan memberikan pembayaran dahulu (DP) oleh kliennya.

3. Dari segi keabsahannya urf ada dua bagian yakni :

a. urf shahih yaitu sesuatu kebiasaan atau 'adah yang tidak manyalahi syari at Islam atau ajaran Islam secara totalitas

b. urf fasid, adalah kebiasaaan atau 'adah yang menyalahi syari'at Islam, meskipun kebiasaan tersebut telah menjadi kebiasaan bagi masyarakat setempat sejak dahulunya. Contoh yang urf fasid adalah hutang piutang dengan riba atau adanya tambahan, semisal $10 \%$ dari keuntungan yang diperoleh dalam dunia usaha merupakan kebiasaan, akan tapi hal itu salah dan dilarang ajaran Islam, atau sogok (penyuapan) dalam perkara.

\section{PENGERTIAN IBADAH DAN RUANG LINGKUPNYA DALAM HUKUM ISLAM}

Ibadah, menurut bahasa, diambil dari kata (Abada, ya'budu, `ibadatan), yang artinya taat, tunduk, turut, ikut, menghambakan diri, dan do'a. Ibadah dalam arti taat dan patuh terhadap perintah Allah, diungkapkan dalam al-Qur'an antara lain:

$$
\text { وما خلقت الجن والانس الاليعبدون. }
$$


Artinya : Dan Aku tidak menciptakan jin dan manusia melainkan supaya mereka menyembah-Ku (mengabdi kepada-Ku). (QS. Adz-Dzariyat: 56).12

Adapun menurut istilah, ibadah berarti tunduk dan patuh, berserah diri kepada hukum, peraturan, dan ketentuan Allah, untuk mencapai ridha-Nya. ${ }^{13}$ Makna ibadah mencakup dua hal yaitu :

a. Penyembahan ( $\left.t a^{`} a b b u d\right)$, yaitu merendahkan diri kepada Allah dengan melakukan segala apa yang diperintahkan-Nya, dan menjauhi apa yang dilarang-Nya dengan penuh kecintaan dan pengagungan kepada-Nya.

b. Sarana dan cara yang dijadikan sebagai bentuk penyembahan (muta'abbad bihi, yakni mencakup segala apa yang dicintai oleh Allah dan diridhai-Nya, baik dalam bentuk ucapan, perbuatan yang nampak terlihat ataupun yang tersembunyi (di hati manusia), seperti dzikir tsir (dalam hati), shalat khusyu', niat, ikhlas, mahabbah ilallah (cinta kepada Allah) dan lain-lain. ${ }^{14}$

Dilihat dari tata cara pelaksanaannya, ibadah dalam Islam dibagi menjadi empat macam;

1. Ibadah Ruhaniyah, yaitu ibadah yang dilakukan oleh rohani, seperti niat berbuat baik, dzikir sir (dalam hati).

2. Ibadah Ruhaniyah Jasadiyah, yaitu ibadah yang dilakukan oleh perpaduan antara rohani dan jasmani, seperti shalat dan puasa.

3. Ibadah Ruhiyah Maliyah, yaitu ibadah ibadah yang dilakukan oleh perpaduan antara rohani dan harta, seperti zakat dan sedekah.

4. Ibadah Ruhiyah Jasadiyah Maliyah, yaitu ibadah yang dilakukan oleh perpaduan antara rohani, jasmani dan harta sekaligus, seperti haji dan umrah.

Jika dilihat dari segi bentuk dan sifatnya, ibadah dapat dikatagorikan menjadi lima kategori, yaitu;

1. Ibadah dalam bentuk perkataan atau lisan, seperti zikir, doa, memuji Allah, membaca al-Qur'an.

2. Ibadah dalam bentuk perbuatan yang telah ditentukan tata caranya, seperti shalat, haji, dan umrah.

3. Ibadah dalam bentuk perbuatan yang tidak ditentukan tata caranya, seperti berbuat baik dan menolong orang dalam kesulitan.

4. Ibadah yang pelaksanaannya dalam bentuk menahan diri, seperti puasa dan I'tikaf.

5. Ibadah yang sifatnya menggunakan hak, seperti memaafkan orang yang bersalah, membebaskan orang yang berhutang dari kewajiban membayar hutang. hlm. 862 .

12 Departemen Agama RI, Al-Qur`an dan Terjemahannya, (Semarang: PT. Kumudasmoro Grafindo, 1994),

${ }^{13}$ Lihat Ramlan Yusuf Rangkuti (ed), Buku Ajar Pendidikan Agama Islam Pada Perguruan Tinggi Umum, tp, 2000, hlm. 98.

${ }^{14}$ M. Ibrahim bin Abdullah at-Tuwaijiri, Ensiklopedi Islam al-Kamil, (Jakarta Timur: Darus Sunnah Press, 2011), hlm. 70 . 
Dilihat dari esensinya, ibadah dapat dibagi menjadi dua bagian ${ }^{15}$;

1. Ibadah Mahdah/khusus (murni), yaitu ibadah yang telah ditentukan tata caranya, waktu dan tempatnya, oleh syari'at dalam rangka hubungan khusus seorang hamba dengan Allah. Contoh ibadah mahdah, seperti shalat, puasa, zakat, haji, dan lainnya.

2. Ibadah Ghairu Mahdah/umum (tidak murni) atau ibadah umum, yaitu segala bentuk hubungan manusia dengan manusia atau manusia dengan alam yang memiliki makna ibadah. Kegiatan manusia dalam hal ini bagi umat yang beriman memenuhi tiga syarat;

a. Perbuatan itu positif, dalam arti mendatangkan manfaat baik untuk diri sendiri maupun orang lain.

b. Dilaksanakan dengan niat yang ikhlas karena Allah semata.

c. Bertujuan menggapai ridha Allah.

Contoh ibadah ghairu mahdah ini seperti, belajar, mencari nafkah, menolong orang susah, melestarikan lingkungan, senyum kepada orang lain, mandi wajib, mandi sunnah, mandi biasa, dan lain sebaginya.

\section{IBADAH ISLAM MENCAKUP KESELURUHAN AJARAN HUKUM ISLAM.}

Sudah jelas bahwa ruang lingkup ibadah dalam Islam amat luas, karena manusia diciptakan agar beribadah kepada Allah SWT. Dengan itu sudah tentu dalam Islam, seluruh kegiatan manusia adalah ibadat kepada Allah SWT. Ibn Taimiyyah (al-'Ubudiyyah: 38) berkata: ibadah ialah kata-nama yang mencakup segala sesuatu yang disukai oleh Allah SWT dan yang diridhai-Nya sama ada perkataan, perbuatan, yang lahir dan batin. Justru itu, sembahyang, zakat, puasa, haji, jujur dalam kata-kata, menunaikan amanah, melakukan kebajikan kepada kedua orang tua, menunaikan janji, amar ma'ruf, nahi mungkar, berjihad menentang orang-orang kafir dan munafiqin, melakukan kebajikan kepada jiran tetangga, anak yatim, orang fakir miskin dan musafir juga hamba sahaya dan binatang, doa, zikir dan bacaan al-Quran, semuanya adalah ibadah."

\section{IBADAH UMAT ISLAM MENCAKUP SELURUH ASPEK KEHIDUPAN DAN SELURUH AGGOTA TUBUH}

Ibadah Islam memenuhi seluruh ruang hidup muslim dan mengatur kehidupan mereka seluruhnya, diawali dengan cara atau adab makan minum, buang air, sampai kepada cara membina negara, politik pemerintahan, kebijakan keuangan dan ekonomi, urusan muamalat dan undang-undang, serta dasar hubungan internasional baik di masa damai maupun di masa perang.

${ }^{15}$ Dalam sebahagian literature menyebutkan bahwa ibadah itu dibagi kepada dua bentuk yaitu ibadah dalam arti sempit dan ibadah dalam arti luas, lebih jelasnya lihat Banbang Subandi dkk (Tim Penyusun MKD IAIN Sunan Ampel Surabaya), Studi Hukum Islam, (Surabaya: IAIN Sunan Ampel Press, 2012), hlm. 52-53. 
Di antara keistimewaan ibadah Islam ialah bahwa ia mencakup seluruh anggota manusia.

a. Ibadah Hati.

b. Ibadah Lidah.

c. Ibadah Pendengaran (Telinga).

d. Ibadah Penglihatan (Mata).

e. Ibadah Tangan.

f. Ibadah hidung.

g. Ibadah Tangan dan Kaki.

h. Ibadah Kemaluan.

\section{TUJUAN DAN HIKMAH IBADAH DALAM HUKUM ISLAM}

Mungkin ada orang akan bertanya: "Kenapa manusia harus beribadah kepada Allah SWT. Kenapa Allah memfardhukan atas manusia supaya beribadah kepada-Nya, sedangkan Dia adalah Tuhan terkaya daripada ibadah itu, dan Dia tidak memerlukan khidmat manusia terhadap-Nya, apakah manfaatnya manusia beribadah kepada Allah SWT.

Sesungguhnya, Allah sama sekali tidak mengambil manfaat daripada hamba-Nya. Dia juga tidak akan termudharat akibat keengganan hamba-Nya dari menyembah-Nya. Keagungan kerajaan-Nya tidak bertambah dengan sebab ibadah manusia, zikir dan tahmid mereka kepada-Nya. Dia adalah Tuhan yang Maha Kaya, dan manusia adalah hambahamba-Nya yang fakir. Hal ini sejalan dengan firman Allah yang artinya: "Dan barangsiapa yang bersyukur maka sesungguhnyadia bersyukur untuk dirinya sendiri. Dan barangsiapayang kufur, maka sesungguhnya Tuhanku Maha Kayadan Pemurah."(QS al-Naml: 40)

Jika Allah SWT. adalah Tuhan yang Maha Kaya secara mutlak, maka mengapakah Dia mentaklifkan hamba-Nya supaya menyembah-Nya. Sesungguhnya jawaban atas pertanyaan ini tersembunyi dalam tabi'at diri manusia itu sendiri, tabi'at tugasnya di muka bumi dan tujuan yang jadikan tujuan di balik kehidupan dunia ini.

Berikut dinukilkan sedikit manfaat yang mungkin didapati di balik ibadat kepada Allah SWT. Al-Imam Fakhruddin al-Razi pernah berkata: “Ketahuilah bahwa barang siapa yang mengetahui manfaat-manfaat ibadah, niscaya nikmatlah dia beribadah, dan beratlah hatinya mau melakukan perkara-perkara lain selain ibadah. Manfaat tersebut dapat dilihat dari beberapa aspek:

Pertama: Bahwa al-kamal yaitu sifat kesempurnaan dicintai, dan dituntut. Hal keadaan manusia yang paling sempurna ialah ketika dia sibuk beribadah kepada Allah, karena hatinya akan bersinar dan gemerlap dengan cahaya Ilahiyyah. Lidahnya akan mendapat kemuliaan dengan kemuliaan zikir dan bacaan, yaitu bacaan al-Qur'an. Anggotaanggotanya akan kelihatan indah dengan keindahan berkhidmat kepada Allah SWT. 
Keadaan-keadaan begini merupakan semulia-mulianya martabat insaniyyah dan derajat kemanusiaan. Tercapainya martabat dan derajat ini adalah puncak kebahagiaan manusia di dunia ini. Apabila puncak kebahagiaan di dunia ini sudah diperoleh, maka sudah tentu ia juga akan memperoleh kebahagiaan yang paling sempurna di akhirat.

Oleh demikian, barang siapa yang telah merasakan martabat dan derajat ini, hilanglah segala keletihan dan rasa berat dalam beribadah, dan niscaya dia akan memperoleh kenikmatan dan manisnya ibadah di dalam hatinya.

Kedua: Ibadah adalah suatu amanah. Firman Allah SWT yang artinya: "Sesungguhnya Kami telah bentangkan amanah ke atas langit, bumi dan gunung, lalu mereka tidak sanggup memikulnya, dan mereka takut menerimanya, lalumanusia memikulnya."

Menunaikan ibadah adalah salah satu dari sifat kesempurnaan yang disukai oleh jiwa. Menunaikan ibadah kepada Allah adalah penunaian separuh dari amanah, dan ia akan menjadi sebab kepada penunaian separuh kedua lagi.

Diceritakan, bahwa seorang sahabat berkata: Saya melihat seorang Arab kampung datang kepintu masjid, lalu turun dari untanya, lalu ditinggalkan untanya dan memasuki masjid dan terus sembahyang dengan penuh ketenangan dan khusyu', berdoa dengan segala apa yang dikehendakinya sehingga kami merasa takjub. Ketika dia keluar, didapati untanya telah hilang, lantas diaberkata: aku telah menunaikan amanah-Mu maka di manakah amanahku? Perawi cerita ini berkata: Kami bertambah heran. Tidak lama dia duduk di situ, sampai datang seorang lelaki menunggang untanya dan menyerahkan unta itu kepadanya.

Al-Imam al-Razi berkata: Iktibarnya, ialah apabila dia telah menjaga amanah Allah SWT. (yaitu beribadah kepadanya dengan sempurna), Allah SWT. menjaga amanahnya. Inilah yang dikehendaki oleh Rasulullah s.a.w. dalam hadis yang dituturkan kepada Ibn Abbas: Artinya: "Jagalah (peliharalah) Allah SWT, niscaya Dia akan menjagamu (memeliharamu)."

Ketiga: Kesibukan beribadah atau keasyikan beribadat adalah suatu perpindahan dari alam al-ghurur kepada alam al-surur, ialah perpindahan dari alam tipu-daya menuju alam suka-ria. Ia juga merupakan perpindahan dari kesibukan bersama makhluk menuju kesibukan bersama Allah SWT. Hal ini sudah tentulah membawa kepada kenikmatan dan kegembiraan yang sempurna.

Diriwayatkan dari Imam Abu Hanifah r.a., bahwa seekor ular telah terjatuh dari atap dan banyak orang lari menjauhkan diri darinya. Abu Hanifah r.a. ketika itu sedang sembahyang, dan beliau tidak sadar akan apa yang terjadi. Ini bukanlah suatu hal yang ganjil, siapapun yang ragu akan hal itu, maka hendaklah dia merujuk ayat al-Qur'an yang menceritakan kisah Nabi Yusuf: Artinya: "Apabila perempuan-perempuan itu melihatnya (yaitu Yusuf), mereka heran terperanjat, sehingga mereka memotong tangan-tangan mereka."(QS. Yusuf: 31)

Perempuan-perempuan yang terperanjat melihat Nabi Yusuf, lantaran ketampanan Nabi Yusuf, sebenarnya hati mereka telah dikuasai oleh perasaan asyik dengan ketampanan 
Nabi Yusuf, yang mana membawa kepada hal tidak sadar diri, sampai mereka terpotong jari-jari tangan mereka. Jika hal ini (yaitu keterpegunan dan keasyikan sampai tidak sedar diri) dapat terjadi padahal seorang makhluk, maka tentulah lebih utama hal yang sama, (yaitu keasyikan yang amat mendalam dalam hati hamba) dapat terjadi terhadap Allah S.W.T. Demikianlah kupasan Imam al-Razi dalam eksperimen beliau untu kmenerangkan manfaat ibadah bagi seorang hamba Allah.

Seseorang yang merasai kenikmatan iman yang benar, dan hatinya diselubungi cahaya keyakinan, dia tidak akan memandang ibadah sebagai ketundukan, atau kepatuhan kepada titah perintah semata-mata, bahkan dia akan mendapati pada ibadah itu sebuah kenikmatan. Kenikmatan akan munajat kepada Allah SWT. dan kenikmatan dengan usaha merebut keredhaan Allah SWT., dimana dia pasti akan merasakan suatu kebahagiaan yang tidak dapat dibandingkan dengan kebahagiaan orang yang hidup mewah di istana mewah, atau dalam timbunan harta benda, dan emas perak. Kebahagiaan orang yang beribadah jauh lebih istimewa dan unik.

Jika dilihat kehidupan Rasulullah Saw. maka akan didapati bahwa baginda Saw. menanti saat-saat ketibaan waktu sembahyang bagaikan penantian seorang yang haus dahaga akan setitis air yang sejuk. Baginda bergegas untuk melaksanakan salat, seumpama bergegasnya seorang yang bermusafir di padang pasir ke arah lembah yang kehijauan. Baginda seringkali berkata kepada Bilal apabila tiba waktu salat, dalam keadaan yang rindu dan mengharap, dengan sabda baginda s.a.w.: Artinya: "Istirahatkan kami ya Bilal dengannya (yaitu dengan sembahyang) wahai Bilal."(HR. Ahmad, Nasaai, Hakim dan Baihaqi).

'Aisyah juga pernah menceritakan, di mana kata beliau:"Telah adalah Rasulullah Saw. bercakap-cakap dengan kami dan kami bercakap-cakap dengan baginda. Apabila tiba waktu sembahyang, baginda seolah-olahnya tidak mengenali kami lagi, kami tidak mengenali baginda. Maka tidak mengherankan jika baginda Saw. bersabda: Artinya: "Dijadikan kesejukan mata hatiku dalam sembahyang."

Selain apa yang dibentangkan di atas, di sana masih banyak tujuan ibadah Islam yang ingin dicapai. Di antaranya sebagaimana yang digariskan oleh Yusuf al-Qardhawi ialah (1985: 95-129):

- Ibadah sebagai makanan ruh

- Ibadah dan ‘Ubudiyyah jalan pembebasan manusia

- Ibadah sebagai ujian

- Ibadah adalah hak Allah SWT. atas hamba-Nya

- Ibadah sebagai cara mendapat pahala

- Ibadah sebagai cara pembersihan jiwa

- Ibadah sebagai akhlak dan akhlak sebagai ibadah 


\section{APAKAH SUATU `ADAH ATAU KEBIASAAN ITU JIKA DIKERJAKAN LANGSUNG MENJADI IBADAH ATAU TIDAK DALAM PERSPEKTI HUKUM ISLAM.}

Sebagaimana telah dijelaskan di atas, bahwa ruang lingkup ibadah itu ada dua yaitu ibadah mahdhah (khusus) ibadah yang telah ditentukan tata caranya, waktu dan tempatnya, oleh syari'at dalam rangka hubungan khusus seorang hamba dengan Allah. Contoh ibadah mahdah, seperti shalat, puasa, zakat, haji, dan lainnya. Adapun ibadah Ghairu Mahdah/umum (tidak murni) atau ibadah umum, yaitu segala bentuk hubungan manusia dengan manusia atau manusia dengan alam yang memiliki makna ibadah.

Selain itu, suatu ibadah yang dilakukan harus ada aturannya, tata caranya, atau aturan syari'atnya. Sesuatu yang dilakukan itu harus berdasarkan norma atau hukum yang ada, jika tidak sesuai dengan aturan yang ada maka perbuatan itu akan menghasikan sesuatu yang tidak bernilai dalam pandangan Islam khususnya dalam pandangan Allah SWT. Nabi Muhammad Saw. telah membuat suatu garisan atau aturan tentang segala perbuatan manusia harus berdasarkan atas niat sesorang, niat itu yang lebih utama dan yang paling utama dalam melaksanakan segala sesuatu.

Hadis Nabi tentang signifikansi niat itu adalah:

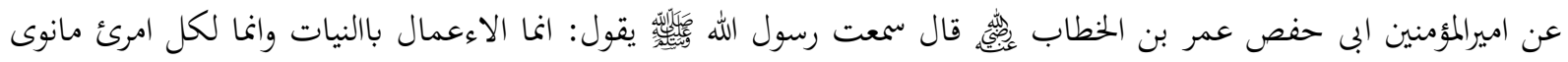

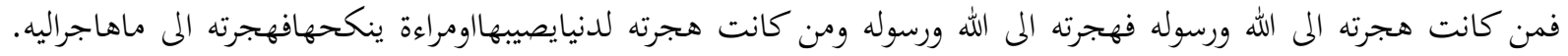

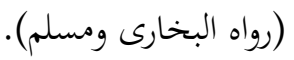

Artinya: “Dari Amiril Mu’minin Abi Hafsh Umar bin Khattab r.a. telah berkata: aku telah mendengar Rasulullah saw, bersabda bahwasanya segala amal perbuatan tergantung pada niat, dan bahwasanya bagi tiap-tipa orang apa yang ia niatkan. Maka barang siapa yang berhijrah menuju (keridha`an) Allah dan rasul-Nya, maka hijrahnya itu ke arah (keridha'an) Allah dan rasul-Nya. Dan barang siapa yang hijrahnya itu karena dunia (harta atau kemegahan dunia), atau karena seorang wanita yang akan dikawininya, maka hijrahnya itu kea rah yang ia tuju tersebut". (HR. Bukhari dan Muslim).

Sejalan dengan hadis di atas, bahwa segala perbuatan hamba Allah harus disertai dengan niat yang baik, jika tidak dibarengi dengan dengan niat maka perbuatannya akan jatuh kepada perbuatan yang tidak punya nilai ibadah apapun. Jika tidak memiliki nilai ibadah, maka ia jatuh kepada `adah atau kebiasaan semata.

Untuk lebih jelasnya dibuat contoh perbuatan atau aktivitas hidup, seseorang yang makan dan minum tidak dinilai sebagai sebuah ibadah bila ia bermaksud atau beniat bahwa makan dan minumnya itu hanya untuk menghasilkan energi semata bagi tubuhnya. Akan tetapai jika ia berniat makan dan minum untuk mendapatkan energi dan agar dapat melakukan ibadah, baik ibadah mahdhah atau ibadah ghairu mahdhah maka perbuatan tersebut menjadi satu nilai ibadah baginya, karena diawali dengan niat yang baik dan hasilnyapun kebaikan. 
Hadis di atas sejalan dengan qa`idah yang ada yaitu: الامور بمقاصدها "segala sesuatu (perbuatan) tergantung pada tujuannya (maksud niatnya)."16 Hal ini deperkuat oleh sebuah hadis yang berbunyi : انما يبعث الناس على نياتم yang artinya : "sesungguhnya manusia itu akan dibangkitkan (untuk memperoleh balasan) sesuai dengan niat masing-masing."

Wudhu dan mandi, dapat berlaku sebagai ibadah, tetapi dapat juga untuk sekedar mendinginkan badan atau membersihkannya. Menahan diri tidak makan dan minum dapat sebagai ibadah (puasa) namun dapat juga untuk upaya penjagaan agar badan tidak terlalu gemuk (diet). Demikian juga halnya seseorang yang duduk di mesjid, selain untuk ibadah dengan niat `iktikaf, dapat jadi dia mempunyai niat hanya sekedar untuk istirahat atau untuk berteduh dari sinar matahari yang amat sangat terik di siang hari.

Memberi sejumlah uang kepada orang lain dapat sebagai hibah, atau sebagai ibadah seperti membayar zakat, sedekah, atau membayar kafarat. Demikian juga halnya dalam menyembelih hewan ternak kambing atau sapi, bisa saja hewan itu disembelih hanya untuk kegiatan pesta semata atau bisa juga dengan niat lain, yaitu untuk taqarrub kepada Allah SWT. Dengan demikian, semua bentuk pelaksanaan suatu perbuatan bisa saja sama antara yang satu dengan yang lainnya, akan tetapi kedudukannya tidak sama, tergantung pada niat masing-masing pribadi secara individu.

Niat harus ada pada permulaan melakukan perbuatan, sedangkan tempat niat adalah di dalam hati. Niat, di samping sebagai alat penilai perbuatan, juga bisa merupakan ibadah tersendiri seperti yang difahami dari hadis Nabi yang berbunyi : نيةالمؤمن خير من عمله (رواه الطبران) "niat seorang mukmin itu lebih baik daripada amalnya (tanpa perbuatan)." Artinya seorang mukmin untuk niat beramal kebaikan karena Allah Swt, kemudian dia tidak dapat melaksanakan niat tersebut maka ia akan mendapatkan pahada dari Allah. Jadi dengan demikian seorang mukmin beramal saja tanpa dibarengi dengan niat kerena Allah maka tidak mendapatkan pahala. Kesimpulannya, segala sesuatu perbuatan yang dilakukan baik ia sebagai suatu kebiasaan ('adah) yang tanpa dibarengai dengan niat, maka perbuatan itu bukan merupakan ibadah kepada Allah SWT.

Namun boleh melakukan sesuatu yang menyalahi syari at Islam jika hal itu merupakan keterpaksaan atau kondisi dharurat, jika tidak dilakukan akan memudhratkan bagi diri sendiri atau tidak akan terjadinya perobahan sepanjang masa. Semisal seseorang boleh melakukan riswah atau tindakan yang bertentangan dengan ajaran Islam, jika tidak dengan cara yang sedemikian rupa (tidak mau melakukan riswah) akan mustahil atau kecil kemungkinan untuk memperoleh jabatan atau posisi yang amat penting tersebut. Akan tetapi jika telah memperoleh posisi atau jabatan tersebut harus dengan niat yang kuat dia akan merobah semua tindakan yang salah atau yang bertentangan dengan ajaran Islam selama ini yang telah dilakukan masyarakat.

${ }^{16}$ Abdullah Mudjib, Kaidah-Kaidah Ilmu Figh, (Jakarta: Kalam Mulia, 2005), 10. 
Demikian juga halnya dengan seseorang yang memakan makanan yang haram ketika masa paceklik, ia memakan makanan babi atau binatang haram lainnya, tapi ia memakannya hanya sekedar untuk menyambung hidup semata. Hal demikian dibolehkan dalam ajaran Islam disebabkan kondisi darurat. Hal ini juga sejalan dengan kaidah hukum yang ada yang berbubyi : ل لضروراة تبيح ل 17 yang artinya: “Kemudharatan-kemudharatan itu membolehkan hal-hal yang dilarang". Hal ini sejalan juga dengan firman Allah yang berbunyi:

18 فمن اضطرغيرباغ ولاعادفلااتم عليه yang artinya: "Akan tetapi barang siapa dalam keadaan terpaksa (memakannya) sedang ia tidak mengiginkan dan tidak pula melampaui batas, maka tidak ada dosa baginya"(QS. al-Baqarah 173).

\section{PENUTUP}

Adat atau kebiasaan merupakan suatu hal yang menyatu dalam kehidupan manusia, sehingga terkadang sulit untuk membedakan mana yang menjadi adat atau kebiasaan dan mana hukum yang sebenarnya. Adat atau kebiasaan itu sering menjadi pertimbangan dalam diskusi-diskusi ilmiah apakah adat tersebut bisa menjadi salah satu sumber penetapan hukum dalam Islam. ${ }^{19}$ Dengan adanya kedekatan atau pergumulan antara hukum Islam dan adat tersebut membuat hukum itu dipengaruhi adat, atau sebaliknya adat mempengaruhi hukum yang ada dalam masyarakat setempat. Tidak mengherankan adanya kaedah yang berbunyi: العادة محكمة Artinya: “Adat kebiasaan dapat dijadikan hukum”.

Namun demikian adatkah yang mempengaruhi hukum atau hukum yang mempengaruhi adat kebiasaan. Hal ini juga perlu adanya diskusi yang cukup dalam agar pergumulan antara keduanya menjadi suatu hal yang dapat memberikan manfaat yang positif terhadap kehidupan masyarakat setempat. Terkadang di daerah tertentu lebih mementingkan adat kebiasaan daripada ajaran Islam yang ada, sebab jika meninggalkan adat setempat akan mendapatkan sanksi adat dari masyarakat setempat dengan sebutan orang yang tak beradat dan tak tau adat.

${ }^{17}$ Abdul Mudjib, hlm. 36.

${ }^{18}$ Departeman Agama RI, hlm. 44.

${ }^{19}$ Lihat lebih lanjut Ratno Lukito, Islamic Law and Adat Encounter: The Experience of Indonesia (Terj.) (Jakarta: INIS, 1998), hlm. 5 . 


\section{DAFTAR PUSTAKA}

Ahmad Fahmi Abu Sunnah, al-'Urf wa al-`Adah fi Ra`yu al-Fuqaha', Mesir: Dar al-Fikr, al'Arabi, t.t.

Bambang Subandi dkk (Tim Penyusun MKD IAIN Sunan Ampel Surabaya), Studi Hukum Islam, Surabaya: IAIN Sunan Ampel Press, 2012.

Dedi Ismatullah, Sejarah Sosial Hukum Islam, Bandung: Pustaka Setia, 2011.

Departemen Agama RI, Al-Qur'an dan Terjemahannya, Semarang: PT. Kumudasmoro Grafindo, 1994.

M. Ibrahim bin Abdullah at-Tuwaijiri, Ensiklopedi Islam al-Kamil, Jakarta Timur: Darus Sunnah Press, 2011.

M. Mustafa Syalabi, Ushul al-Figh al-Islami, Beirut: Dar an-Nahdah al-`Arabiyah, 1986.

M. Yasir Nasution, Hukum Islam dan Signifikansinya dalam Kehidupan Masyarakat Modern, Pidato Pengukuhan Guru Besar IAIN-SU tanggal 7 Januari 1995.

Nasrun Haroen, Ushul Figh I, Jakarta: Logos Wacana Ilmu, 1997.

Ramlan Yusuf Rangkuti (ed), Buku Ajar Pendidikan Agama Islam Pada Perguruan Tinggi Umum, tp, 2000.

Ratno Lukito, Islamic Law and Adat Encounter: The Experience of Indonesia, Jakarta: (Terj.) INIS, 1998.

Subhi Mahmasani, Filsafat at-Tasyri fi al-Islam, Beirut: Dar al-Kasysyaf lin-Nasyr wa atTiba ah wa at-Tauzi, 1952.

Suparman Usman, Hukum Islam: Asas-asas dan Pengantar Hukum Islam dalam Tata Hukum Indonesia, Jakarta: Gaya Media Pratama, 2001. 
FITRAH Vol. 01 No. 2 Juli-Desember 2015

Peningkatan Hasil Belajar Dan Motivasi Melalui

Penerapan Model Discovery Learning Berbantuan Multimedia Pada Materi

Jujur, Amanah, Dan Istiqamah 